Cahiers $d u$ MONDE RUSSE

\section{Cahiers du monde russe}

Russie - Empire russe - Union soviétique et États indépendants

$47 / 3$ | 2006

La Russie au XVIIIe

\title{
Building an infrastructure of empire in russia's eastern theater 1650s-1840s
}

JOHN LEDONNE

\section{OpenEdition}

\section{Journals}

Édition électronique

URL : https://journals.openedition.org/monderusse/8841

DOI : $10.4000 /$ monderusse. 8841

ISSN : $1777-5388$

\section{Éditeur}

Éditions de l'EHESS

\section{Édition imprimée}

Date de publication : 23 septembre 2006

Pagination : 581-610

ISBN : 978-2-7132-2097-5

ISSN : $1252-6576$

Référence électronique

JOHN LEDONNE, "Building an infrastructure of empire in russia's eastern theater 1650s-1840s », Cahiers du monde russe [En ligne], 47/3 | 2006, mis en ligne le 01 janvier 2007, consulté le 02 septembre 2022. URL : http://journals.openedition.org/monderusse/8841 ; DOI : https://doi.org/ 10.4000/monderusse.8841 
chercher : repérer : avancer

Cet article est disponible en ligne à l'adresse :

http://www.cairn.info/article.php?ID REVUE=CMR\&ID NUMPUBLIE=CMR 473\&ID ARTICLE=CMR 473 0581

\title{
Building an infrastructure of empire in russia's eastern theater 1650s-1840s
}

\author{
par John LEDONNE
}

\section{Editions de l'EHESS | Cahiers du monde russe}

\author{
$2006 / 3$ - Vol 47 \\ ISSN 1252-6576 | ISBN 9782713220975 | pages 581 à 610
}

\footnotetext{
Pour citer cet article :

- LeDonne J., Building an infrast ructure of empire in russia's eastern theater 1650s-1840s, Cahiers du monde russe 2006/3, Vol 47, p. 581-610.
}

Distribution électronique Cairn pour les Editions de l'EHESS.

(C) Editions de l'EHESS. Tous droits réservés pour tous pays.

La reproduction ou représentation de cet article, notamment par photocopie, n'est autorisée que dans les limites des conditions générales d'utilisation du site ou, le cas échéant, des conditions générales de la licence souscrite par votre établissement. Toute autre reproduction ou représentation, en tout ou partie, sous quelque forme et de quelque manière que ce soit, est interdite sauf accord préalable et écrit de l'éditeur, en dehors des cas prévus par la législation en vigueur en France. Il est précisé que son stockage dans une base de données est également interdit. 


\section{BUILDING AN INFRASTRUCTURE OF EMPIRE IN RUSSIA'S EASTERN THEATER 1650s-1840s*}

The purpose of this article is to present in condensed form the evolution of Russia's policy toward the administration of its territorial peripheries from the $1650 \mathrm{~s}$, when a sustained expansionist drive truly began, to the 1840s, when the empire reached the height of its power, even before the annexation of Central Asia and the coastal Far East. But the empire was so large that such a topic would far exceed the permissible limits of an article, and I propose to discuss only one of the three theaters, in which the emergence of a sui generis continental ensemble took place. This Russian empire cannot be compared with the overseas empire of the European powers, but must be studied on its own terms. I seek here to lay the ground for such a study by tracing the evolution of the institutional framework that made possible its construction in a single theater. Whether a similar evolution can be traced in the southern theater (facing the Habsburg and Ottoman empires) and the western theater (facing Swedes, Poles, and Prussians) will require a separate study. I also intend to raise the question - which cannot be answered until we first gain a clearer understanding of the institutional framework necessary to carry out religious, social, and fiscal policies - whether the Russians were actually building an empire in the seventeenth and eighteenth centuries. A case can be made for the fact that they were not, until further expansion took them beyond the natural limits of the agricultural zone in all three theaters. Such a contention can, of course, be challenged, but I am convinced that many of our assumptions on the creation and management of the empire need to be revised. Thus, the topic discussed here stands between two other large issues - the building of an institutional framework in all three theaters, and the transformation of an expanding and integrated core into a continental empire.

* This article is the outcome of a presentation made at the Ludwig-Maximilian University in Munich on May 15, 2006. I remain grateful to Professor Martin Schulze Wessel for his invitation and to the participants who contributed to a lively discussion afterwards. 
The eastern theater of operations can best be represented as a triptych. Its left-hand panel was the Caspian basin watered by the Volga, the Kura, and Ural rivers, extending to the broad mountainous zone between the Caucasus on the one hand and the Taurus and Zagros chains on the other, both of which formed the Heartland's periphery. ${ }^{1}$ This frontier was a zone of competing ambitions between Russians, Turks, and Persians. Its central panel was the basin of the Kara Sea drained by the Ob, the Irtysh, and their tributaries, and - south of the watershed formed by the Ustiurt upland, the Hungry Steppe, and the Balkhash depression - the Aralo-Caspian depression known as Central Asia, which bordered on the Persian core to the Zagros Mountains. Its eastern panel was the basin of the Laptev and East Siberian Seas, forming, with the Kara Sea, the continental fringe of the Arctic Ocean. It was watered by the Lena River and its tributaries as well as those of the Enisei, and reached as far as the Mongolian Altai and the Gobi Desert, beyond which began the approaches to the Chinese core area. The triptych revolved around two hinges: the Ural Mountains and the Enisei River.

This immense theater had once formed the greater part of the Mongol Empire consisting of the Kipchak khanate (with medieval Rus'), the Jagatai ulus, the Ilkhan federation (Persia, the southern Caucasus, and Afghanistan), and Mongolia. ${ }^{2}$ By the sixteenth century, however, Moscow was on the offensive. The annexation by Ivan IV of the Kazan khanate in 1552, that of Astrakhan four years later, and of the Siberian khanate in 1583 , created, with the founding of Tobolsk in 1587, three administrative and military headquarters. The three khanates had emerged as the successor states to the Kipchak khanate when it fell apart in the second half of the fifteenth century. This vast frontier, with the three khans replaced by voevody in each of the three headquarters, with extensive civil and military authority, was placed at first under the overall jurisdiction of the Chancery of Foreign Affairs (Posol'skii Prikaz) and, after a short interval between 1595 and 1599, under that of the Siberian desk of the Kazan Chancery (Prikaz Kazanskogo Dvortsa). This remained the case until 1637 when, most likely in connection with the arrival of the Kalmyks in western Siberia, a separate Siberian Chancery was created, while the old lands of the Kazan and Astrakhan khanates remained the responsibility of the Kazan Chancery. But it also happened in the early years that both chanceries were managed by the same boyar, showing that the government continued to look at those territories as a single administrative entity. ${ }^{3}$

1. John P. Le Donne, The Russian Empire and the World, 1700-1917: The Geopolitics of Expansion and Containment (New York-Oxford: Oxford Univerity Press,1997), 1-13.

2. Georgii V. Vernadski, A History of Russia: The Mongols and Russia (New Haven: Yale University Press, 1953), 70-80.

3. Igor' P.Ermolaev, Srednee Povolzh'e vo vtoroi polovine XVI-XVII VV. Upravlenie Kazanskim kraem (Kazan, 1982), 52-60; Istoriia Sibiri. Vol. 1-5. (L., 1968-1969), here vol. 2, 124-125; Basil Dmytryshyn, "The Administrative Apparatus of the Russian Colony in Siberia and Northern Asia, 1581-1700," in Alan Wood, ed., The History of Siberia: From Russian Conquest to Revolution (London-New York: Routledge, 1991),19-25; and Raymond H. Fisher, The Russian Fur Trade, 1550-1700 (Berkeley-Los Angeles: University of California Press, 1943), 43, 123-125. For the Conquest see also Ruslan Skrynnikov, Sibirskaia ekspeditsiia Ermaka (Novosibirsk: Nauka, 1982), 113-18, 138-41, 150-57. 
The two chanceries were central agencies with a territorial, rather than a functional, jurisdiction, a distinctive, but not exclusive, feature of the pre-Petrine administrative system. They enjoyed a plenitude of power in their region and were responsible for its management and military security, even for diplomatic relations with China, the Mongols, the steppe nomads, and the Caucasian highlanders. The Siberian Chancery also had a Sable Treasury (Sobolinaia Kazna) which stored the furs sent from Siberia, with a staff of Moscow merchants to assess their value and sell those which the Romanov house chose not to keep. Such vast responsibilities explain why the chiefs of those two chanceries (called judges or chief judges) belonged to prominent families in the ruling elite, and one even detects a sharing of the spoils between the two emerging networks of political families. Boris Golitsyn (1654-1714) was appointed in 1684 to head the Kazan Chancery and remained in office until his death, followed by the closing of the chancery in 1714 . He was one of Peter I's tutors; one of his nieces married Fedor Naryshkin, Peter's uncle, and another married Mikhail Kurakin, Peter's brother-in-law. The last chief of the Siberian Chancery, Matvei Gagarin (+1721), was a cousin of Ivan Romodanovskii, who married Anastasia Saltykova, sister-in-law of Ivan V, Peter's half brother. ${ }^{4}$ Their niece would become the Empress Anna Ivanovna in 1730.

The local agents of the two chanceries were voevody appointed in towns or forts scattered across an immense and sparsely populated territory. Sixty-seven towns were in the jurisdiction of the Kazan Chancery, but only 13 had voevody in 1690; the others depended on the most substantial settlements. In the whole of Siberia there were only 19 voevody. They were all equal in theory, and reported directly to their respective chancery. In fact, however, some enjoyed a higher status and became centers of regional razriady. In the eastern theater there were six razriady by the end of the seventeenth century, with headquarters in Kazan, Tobolsk, Tomsk, Eniseisk, Yakutsk, and Irkutsk, the last four founded in 1604, 1618, 1632 and 1652 respectively. All voevody were appointed by the Razriad in Moscow, which emerged during the reign of Alexei Mikhailovich (1645-1676) as a kind of super-chancery in charge of all government appointments and central military staff. 6 The relationship between the razriadnyi voevoda and the simple voevoda was not clear, but it must have been a kind of dual subordination, to the chancery in Moscow that insisted on direct contact, and to the regional (razriadnyi) voevoda, a system well adapted in normal times to the management of distant lands with which Moscow could maintain all but a tenuous link. This Muscovite administrative system remained in existence until the reform of 1708 , to which we now turn.

4. Petr Dolgorukov, Rossiiskaia rodoslovnaia kniga, vol. 1-4 (SPb., 1854-1857), here vol. 1, 237-250, vol. 2, 51, 68-85.

5. Aleksandr P. Barsukov, Spiski gorodovykh voevod i drugikh lits voevodskogo upravleniia XVII stoletiia (SPb., 1902), passim.

6. Istoriia Sibiri, vol. 2: 124-127; Richard Hellie, Enserfment and Military Change in Muscovy (Chicago: University of Chicago Press, 1971), 218; and Anatolii V. Chernov, Vooruzhennye sily russkogo gosudarstva V XV-XVII VV. (M., 1954), 170-171, 188. 
In December 1708, an imperial decree announced the division of the empire into eight provinces (gubernii), each headed by a governor, who oversaw a number of voevody renamed commandants in 1710 . The reform must be placed in the context of the imminent invasion of Russia by Charles XII of Sweden, an emergency with which the ponderous Muscovite system of chancery at the center and a large number of voevody was no longer able to cope. ${ }^{7}$ The reform marked a giant step in the administrative unification of a vast empire, abolished most of the central agencies, and transferred their jurisdiction to eight governors. Their responsibilities resembled in the civilian sphere those of the military commanders in the field, who coordinated the operations of their regiments under the overall guidance of the tsar himself. The governors were not given any instruction spelling out their jurisdiction and powers, but were held responsible for the timely collection of recruits and taxes, without which the war effort would have been doomed at a critical time.

The territory of the former Kazan and Astrakhan khanates remained combined in a new Kazan province, whole of Siberia became a single province, governors were appointed in Kazan and Tobolsk, and the Kazan and Siberian chanceries were closed. In 1717, however, the Astrakhan territory was split off to form a separate province, and its senior commandant was replaced by a governor who did not assume his post until 1719. That year, some provinces were divided into subprovinces (provintsii), headed by a voevoda subordinated to the governor. ${ }^{8}$ By 1721, Kazan province had been divided into six provintsii and 22 uezdy, Siberia into three provintsii and 23 uezdy. The smaller Astrakhan province with 13 uezdy (districts) had no provintsii. ${ }^{9}$

Peter's governors were not only high-ranking members of the ruling elite, they were also related to the Romanov house. ${ }^{10}$ Moreover, the continuity with their predecessors in the Kazan and Siberian Chanceries was striking. Gagarin in Tobolsk (1708-1719) had been the last chief of the Siberian Chancery, following a stint in Siberia as voevoda in Irkutsk and Nerchinsk. His successor, Alexei Cherkasskii (1719-1724), also belonged to a family that had given seven voevody in the eastern theater. The third Tobolsk governor, Mikhail Dolgorukov (17241727), had no such background. He was rather an example of the unfortunate practice of occasionally sending to a distant periphery a member of the elite who

7. John LeDonne, Absolutism and Ruling Class: The Formation of the Russian Political Order 1700-1825, (New York: Oxford University Press, 1991), 68-74.

8. Polnoe Sobranie Zakonov Rossiiskoi Imperii (hereafter PSZ), vol. 5 (SPb., 1830), 3380 (1719).

9. Iurii V. Got'e, Istoriia oblastnogo upravleniia v Rossii ot Petra I do Ekateriny II (M., 1913), 110. For Siberia in particular see Mikhail O. Akishin, Rossiiskii absoliutizm i upravlenie Sibiri XVIII veka: Struktura i sostav gosudarstvennogo apparata (M.-Novosibirsk, 2003).

10. For a general introduction to this ruling elite see J. Le Donne, "Ruling Families in the Russian Political Order 1689-1825," Cahiers du Monde russe et soviétique, 28, 3-4 (1987): 233-322. 
had fallen out of favor: he had been implicated in the investigation of Tsarevitch Alexei. He was also illiterate. In Kazan, the three governors, Petr Apraksin (17081712), Petr Saltykov (1712-1719), and Alexei Saltykov (1719-1725), and Artemii Volynskii in Astrakhan (1719-1725), were also relatives of the tsar. ${ }^{11}$

Although the position of Kazan governor was crucial in the articulation and the execution of a theater strategy in the east, the two most ambitious and powerful proconsuls during Peter's reign were Gagarin and Volynskii. Gagarin, whom greed and dishonesty would eventually lead to the gallows in $1721^{12}$, had received samples of gold dust supposedly found in abundance in the mysterious city of Yarkend on the Silk Road, whose location the Russians could only guess, but which promised to lead them to India and its reportedly fabulous wealth. Finding a way to India in the search for specie was the major objective of eastern theater strategists. Gagarin was instrumental in getting the tsar to send an expedition led by Lt. Colonel Ivan Buchholz from Tobolsk up along the Irtysh, beyond which it would reach Yarkend, occupy it, and leave a garrison as a supporting base for deeper penetration toward India. It failed. A second expedition led by Guard Major Ivan Likharev managed to reach Lake Zaisan on the foothills of the Mongolian Altai in 1719, suffered heavy losses at the hands of the Zunghars, and was forced to withdraw the following year..$^{13}$

But both expeditions resulted in an enormous extension of the Siberian governor's sway in the eastern theater. Both officers built forts on the Irtysh: Omsk in 1716, Zhelezensk in 1717, Semipalatinsk in 1718 - Buchholz's withdrawal did not stop attempts to build forts between Tobolsk and Lake Yamyshev, where Siberia got its supply of salt - and Ust-Kamenogorsk in 1720. These forts became the major building blocks of an Irtysh « Line » which enabled the Russians to project power deep into the steppe to the gates of western Mongolia.

11. These governors, except for Dolgorukov, also belonged to families well represented in the eastern theater. Ten more Gagarins served there as voevody in the seventeenth century, including two in Kazan and Astrakhan. Six more Cherkasskiis were voevody in Kazan, Alatyr, and Astrakhan; four more Saltykovs in Siberia and Astrakhan, and another two in Samara and Ufa; and 13 more Volynskiis: 5 in Siberia, 1 in Kazan, 2 in Astrakhan, 1 in Terki (Terskii gorodok), 1 in Terki, Tomsk, and Kazan, 1 in Tiumen and Ufa Astrakhan, 1 in Berezov and Terki, 1 in Samara and Astrakhan: see Barsukov, passim. Artemii Volynskii was also related to Princess Praskovia Sibirskaia, a descendant of Kuchum, the last khan of the Siberian khanate. For the investigation of Tsarevitch Alexei see Paul Bushkovitch's major contribution in his Peter the Great. The Struggle for Power, 1671-1725 (Cambridge, UK: Cambridge University Press, 2001), 339-425. For Mikhail Dolgorukov see 405-406, 418, 423, 429-430.

12. On Gagarin's malversations see Mikhail O. Akishin, Politseiskoe gosudarstvo i Sibirskoe obshchestvo. Epokha Petra Velikogo (Novosibirsk: Avtor, 1996), 191-204.

13. Russkii biograficheskii slovar' (hereafter RBS), 25 vol. (SPb., 1896-1918), here vol. 3 (1908), 564-565; Zhanuzak Kasymbaev, Gosudarstvennye deiateli kazakhskikh khanstv (XVIII V.) (Almaty: Bilim, 1999-2001), 7-12; Petr A. Slovtsov, Istoricheskoe obozrenie Sibiri (Novosibirsk: Ven Mer, 1995), 250-253; Maurice Courant, L'Asie centrale au XVII et XVIII siècles: empire Kalmuk ou empire Mantchou? (Lyon: A. Rey, 1912), 66-67; and Mezhdunarodnye otnosheniia v tsentral'noi Azii XVII-XVIII veka. Dokumenty i materially, 2 vol. 1-2 (M.: 1989), here vol. 1, 232-240. 
Buchholz's expedition was but one prong in a broad pincer movement directed against Central Asia. That same year, in 1715, Prince Alexander (Bekovich) Cherkasskii, a son-in-law of Boris Golitsyn and brother-in-law of Governor Cherkasskii, sailed from Astrakhan with some 4,000 men for the Mangyshlak Peninsula on the other side of the Caspian. His instruction from the tsar was to find the exact location of Yarkend, whether it was connected with the Caspian by a water route; to determine whether the course of the Amu Daria could be deflected once again toward the Caspian; to induce the Khiva khan to become a subject of the empire; to inquire about the possibility of making Bukhara a tributary state; and, of course, to find the way from there to India. In Peter's mind, both expeditions were seen as a single move seeking to establish Russian influence between the Amu Daria and the Altai; they also implied a claim to the inheritance of the Mongol Empire in the remainder of the Kipchak khanate and Transoxiana. Cherkasskii's expedition, which had been launched from Kazan via Astrakhan, failed before the gates of Khiva in 1717, its members, including Cherkasskii, massacred on the khan's orders. ${ }^{14}$

Cherkasskii's expedition was also one prong of a second pincer movement directed against Central Asia. Again in 1715, Volynskii was sent on a commercial mission to the shah in Isfahan, in fact, to collect intelligence on the condition of the country, and to find out if any river flowed from India to the Caspian. ${ }^{15} \mathrm{He}$ returned convinced that the collapse of the Safavid dynasty was imminent, and that the time had come to make war on Persia in order to acquire its northern provinces fronting the Caspian. These provinces would lead to Khorasan and Herat and, eventually, to India, and would give the Russians a chance to establish a protectorate over Persia, bringing into the orbit of the empire this once major component of the Chingissid empire. The war began in 1722 with a large force of 29,000 regular troops and 20,000 Cossacks with 5,000 sailors. On the way to Derbent, the tsar met a young naval officer, Fedor Soimonov, a future governor of Siberia, who told him that the Russians were now established in Kamchatka and that eastern India was only a short distance away (!). ${ }^{16}$ Obviously, the Russians could then launch yet another huge pincer movement against India from the west and from the east - a remarkable spatial but also wildly unrealistic perspective. But the war did not go well, largely because of logistical difficulties and the appearance of Ottoman forces in the eastern Caucasus. Nevertheless, Russia did gain Derbent and Baku, the coastal road to Persia, and three northern provinces, although only one (Gilian) was

14. On Cherkasskii see RBS, vol. 22 (1905), 177-183. For the campaign see D. Golosov, "Pokhod v Khivu v 1717 godu," Voenny Sbornik, no. 10 (October 1861): 303-364. See also A. Popov, Snosheniia Rossii s Khivoiu i Bukharoiu pri Petre Velikom(SPb., 1853), 3-31.

15. Petr. P. Bushev, Posol'stvo Artemiia Volynskogo v Iran v 1715-1718 gg.: po russkim arkhivam (M.: Nauka, 1978), 257-260; Dmitrii A. Korsakov, "Artemii Petrovich Volynskii. Biograficheskii ocherk," Drevniia i Novaia Rossiia, vol. 1 (Jan.-April 1876): 45-60, here 5160; and Nina G. Kukanova, "Russko-iranskie torgovye otnosheniia v kontse XVII -nachale XVIII v.," Istoricheskie Zapiski, vol. 57 (1956): 232-254.

16. Sergei M. Solov'ev, Istoriia Rossii s drevneishikh vremen, vol. 1-15 (M., 1960-1966), here vol. 9, 377 (russkim ot Kamchatki blizko). 
effectively occupied. But it could gain no staying power in such an inhospitable land, had to retrocede all its gains in 1732 and 1735, and withdrew behind the Terek River. ${ }^{17}$ These failures brought about a strategic reassessment after Peter's death. Anna Ivanovna's reign (1730-1740) marked a return in some ways to the policies of pre-Petrine Muscovy. The importance of the governor's office was downgraded, with its subordination, as a rule, no longer to the Senate but to the individual colleges and chanceries. In Kazan and Astrakhan, Kazan and Astrakhan governors were subordinated to the commander in chief of the "Southern Corps » (nizovyi korpus) based in Nizovaia Pristan: its 20,000 men served as an occupation force in the territory annexed from Persia in 1723.18

The Siberian Chancery was restored in 1730 under Ivan Sheremetev, a close relative of the Cherkasskiis. In Tobolsk, there was only a vice-governor from 1736 to 1741 , but the government also appointed another vice-governor in Irkutsk in 1736, when that city became the capital of another provintsiia; he was placed directly under the Siberian Chancery. ${ }^{19}$ It was the first step in the administrative recognition of the natural division of Siberia between a western part from the Urals to the Enisei River, and an eastern part, from the Enisei to the Sea of Okhotsk, that is, between the central and the eastern panels of the triptych. In Okhotsk, a separate administration was created in 1731 to develop the port which would be independent of the Yakutsk voevoda. The move had been recommended by Captain Vitus Bering, who led two expeditions to explore the northern Pacific between Kamchatka and Alaska - and who probably did not believe, unlike Soimonov, that India was close by. Okhotsk would become the major transfer point for officials, troops, and trappers coming overland from Yakutsk to board ship on their way to Kamchatka. Its first commander, Major General Grigorii Skorniakov-Pisarev, had been a protégé of Peter's all powerful favorite, Alexander Menshikov, who lost out in the power struggle after the tsar's death and was banished in 1727 to Berezov in the wasteland of the lower Ob valley. Petropavlovsk on Avacha Bay on the Pacific coast of Kamchatka was founded in 1740, but would not replace Okhotsk until much later. ${ }^{20}$ The creation of Irkutsk provintsiia, with Selenginsk, Russia's most forward military headquarters on the way to Mongolia, and of a separate administration in Okhotsk built an infrastructure of empire in the third panel of the triptych, to support both a conservative posture toward the Manchu empire after the border treaty of 1728 and potentially a forward policy in the northern Pacific.

17. For the Persian campaign see Vikentii P. Lystsov, Persidskii pokhod Petra I, 1722-1723 (M., 1951), 50-53, 174-178. See also Boris Nolde, Formation de l'Empire russe, 2 vol. (P.: Institut d'Études slaves, 1952-1953), here, vol. 2, 331-39.

18. Platon I. Baranov, Opis' imennym Vysochaishim ukazam i poveleniam, khraniashchiasia $V$ S.-Peterburgskom Senatskom Arkhive, za XVIII vek, vol. 1-3, (SPb., 1872-1878), here vol. 2, N.1715.

19. PSZ, vol. 9 (1830), N. 6876 (1736)

20. PSZ, vol. 8 (1830), N. 5813 (1731); see also A. Sgibnev, "Okhotskii port s 1649 po 1852g.," Morskoi Sbornik, no. 11 (November 1869): 1-92, here: 11-28. 
However, the strategic reassessment of Peter's policies was most evident in the other two sectors of the eastern theater, in the other two panels of the triptych. The men who were instrumental in shaping an imperial policy there - Volynskii, who was Kazan governor from 1725 to 1727 , Ivan Kirilov, the Senate secretary, and Vasilii Tatishchev, director of the Ural mines, commander of the Orenburg « Expedition, » and later governor of Astrakhan (1741-1745) - had all grown to manhood during Peter's reign, were «fledglings» from his nest, as the contemporaries saw them. ${ }^{21}$ They shared the former emperor's ambitions, but not quite his impetuosity, if only because they served in the field and faced the practical difficulties which Peter had so often overlooked.

The emphasis would no longer be on long range projections of military power which could not be sustained, but on the creation of a logistical base from which the expansion could resume at a later date. Moreover, it had become painfully obvious that building such a base was inextricably linked with the integration of the highlanders in the Caucasus and the nomads in the steppe into an administrative and military infrastructure, into an infrastructure of empire, that would either crush their resistance or so weaken them politically that they would become reliable clients of the empire. The lack of a logistical base and the constant insecurity of the frontier precluded the continuation of Peter's policy of deep strategic strikes in the eastern theater for the foreseeable future.

The immediate problem consisted in building an artificial boundary across a boundless steppe stretching from the Terek to the Altai, but the Russians had gained considerable experience in the southern theater during the preceding century. In the 1640s, they had built the so-called Belgorod Line from the Ukrainian border across the Oka-Don corridor to beyond Tambov, from which an extension called the Simbirsk Line was built in the 1650s. ${ }^{22}$ Three generations later, the $1730 \mathrm{~s}$ witnessed the beginning of a massive construction program to extend this defensive perimeter across the Volga for the purpose of restraining the Kalmyks, separating them from the Bashkirs, and the Bashkirs from the Kazakhs, containing the Kazakhs, and protecting the settlements and the Altai mines against the Zunghars, who were in a semi-permanent state of hostility with the Manchu dynasty. Between the Altai and Lake Baikal, mountains created an insurmountable obstacle. Beyond the lake, Russia was at peace with the dynasty; the Irkutsk vice-governor and the Selenginsk commandant defended Russian interests whenever disputes arose, chiefly over matters of trade and the return of fugitives from both sides.

Beginning in 1736, a line of forts was built along the Terek toward its elbow, where Mozdok would later be built in 1763. Further north, between the elbow of the Don and that of the Volga, the Tsaritsyn Line, begun in 1717, was completed in

21. Iurii Smirnov, Orenburgskaia ekspeditsiia (komissia) i prisoedinenie Zavolzh'ia $k$ Rossii v 30-40-e gg. XVIII veka (Samara: Samarskii Universitet, 1997) discusses Kirilov's and Tatishchev's activities, 16-47.

22. Hellie, Enserfment and Military Change, 178, 214 and V.Zagorovskii, Belgorodskaia cherta, (Voronezh, 1969). 
1732. It was manned by the Volga Cossack Host ( voisko), blocked the entrance into the Russian core, and advanced the border of the empire 600 kilometers south of the Simbirsk Line across still nearly deserted territory, but into which settlers were beginning to move. The Volga upriver to Samara formed a natural boundary between Russia and Kalmyk country. Another line of forts was built along the Samara to its watershed with the valley of the Ural River: it separated Bashkirs from Kalmyks. From there downriver to Gurev near the Caspian coast a Ural Cossack Host served to separate Kalmyks from Kazakhs. Moving upriver, more forts, also built in the 1730s, formed the Orenburg Line. This combination of natural and artificial lines formed a defensive perimeter from the Terek to the headwaters of the Ural and guarded the approaches to the core in the Caspian basin. $^{23}$

In western Siberia, Omsk became the hub of another defensive perimeter stretching in two directions: westward, across the Ishim to the Tobol and from that river to the Miass, which connected this «Ishim Line» with the Orenburg Line; and southward, along the Irtysh to Ust-Kamenogorsk to form the «Irtysh Line. » Both lines imposed a linear boundary upon the Kazakhs who found themselves excluded from some of their better pastures. The construction of a « Kolyvan Line » across the Altai would not take place until the 1750s. But the lines, known collectively as the Siberian Line, served the additional purpose of creating a state boundary, not by treaty, since the nomads did not recognize linear boundaries, but simply by the decision of military commanders who showed a preference for rivers and, where there was none, simply drew a line across the steppe. Such a policy had the curious effect of creating two types of imperial subjects: those who now lived behind the line, the «internal» subjects, and those who still roamed the steppe beyond the line, the «external » subjects, whose elders had taken the oath of allegiance to the crown - like the Kazakhs of the Western Horde - but who lived beyond the borders of the empire in a juridical no man's land. ${ }^{24}$ Their existence was a constant reminder that the boundary was not a permanent but a temporary feature inviting future advance into the seemingly endless steppe and, in the Caucasus, even across the mountains.

23. Alton Donnelly, The Russian Conquest of Bashkiria 1552-1740: A Case Study in Imperialism (New Haven:Yale University Press, 1968), 161-173 and maps; and "Opisanie Zakamskikh linii," Vestnik Imperatorskogo Russkogo Geograficheskogo Obshchestva (hereafter VIRGO) vol. 1 (1851): 57-78. See also Petr I. Rychkov, Istoriia Orenburgskaia po uchrezhdenii Orenburgskoi gubernii (Ufa, 2001), 176-181.

24. I came across this distinction in Chancellor Mikhail Vorontsov's "Opisanie sostoianiia del vo vremia Gosudaryni Imperatritsy Elizavety Petrovny," in Arkhiv kniazia Vorontsova, vol. 140 (M., 1870-95), here vol. 25 (1882), 272-312, 297. Vorontsov refers to the Bashkirs as vnutrennyi narod. The implication was that the Kazakhs, for example, were an "external people." In this connection one can use with profit the concept of "internal peripheries:" see for example Hans-Heinrich Nolte, ed., Innere Peripherien in Ost und West (Stuttgart: Franz Steiner Verlag, 2002), 7-15, and by the same author, Internal Peripheries in European History (Göttingen: Muster-Schmidt, 1991), 1-2, 5-27. The three Kazakh hordes are usually called the Small, Middle, and Large Hordes, a misnomer since the Large was not the largest; it also tells nothing about their locations. I prefer to call them the Western, Central, and Eastern Hordes. 
Russia's withdrawal from Persia and Transcaucasia moved the center of gravity of its presence in the Caspian basin to the valley of the Ural, where Ivan Kirilov arrived in 1734 with an instruction from the Senate to build a fort called Orenburg at the confluence of the Ural and Or rivers. It was moved downstream in 1739 and to its present location in 1742. The new fort would become the capstone of Russia's infrastructure of empire beyond the Volga and the Enisei, one of the three military headquarters - with Astrakhan and Omsk - facing the nomadic world in the basin of the Caspian and Kara seas, and linking the triptych's western and central panels. The instruction envisioned a vast program of political and commercial expansion into Central Asia and the building of a logistical base on the edge of the steppe, from which the domestication of the nomad would pave the way for a resumption of military expansion. The recognition of Russia's suzerainty by the khan of the Western Horde in 1730 had been a first and major step toward the eventual incorporation of the Kazakhs into the empire. ${ }^{25}$

The building of a fort on the banks of the Ural represented a bold projection of Russian power across Bashkiria from the Kama River, which had been until then a rough periphery of Russia's presence in the region. It also triggered a massive rebellion by the Bashkirs, who well understood that the arrival of soldiers and the building of an Orenburg Line would be followed by an influx of Russian peasants to till the rich land of Bashkiria. Verkhneuralsk was built on the watershed between the Ural and Ui rivers, where the eastern slope of the southern Urals merges with the great plain of Siberia, to become the logistical base for the garrisons in the region. In 1737, a new Iset provintsiia was created, its capital in Chebarkul (moved to Cheliabinsk in 1743), encompassing the valley of the Iset and the Miass as well as the trans-Ural Bashkir lands. ${ }^{26}$ Its voevoda and that of Ufa were subordinated to Kirilov's successor, Privy Councillor Vasilii Tatishchev, replaced in 1739 by Lt. Gen. Vasilii Urusov, the descendant of a Nogai chieftain.

\section{2}

By the end of the 1730s, Russia's growing military presence in the steppe drew the government's attention to the shortcomings of its regional administrative infrastructure in the eastern theater. Until then, the empire's grip on its peripheral regions had been relatively weak. The two Baltic provinces and the left-bank Ukraine retained considerable autonomy. Russia withdrew from Transcaucasia. Elsewhere, the empire was still very much a unitary state, even with the restoration of the Siberian Chancery. The instruction of 1728 spelled out the jurisdiction of the governors and voevody everywhere, including the eastern theater, but Siberia's

25. Donnelly, Russian Conquest, 59-63. See also an excellent introduction to Russian expansion in the region in Willard Sunderland, Taming the Wild Field: Colonization and Empire on the Russian Steppe (Ithaca: Cornell University Press, 2004), 46-50.

26. PSZ, vol. 10 (1830), N. 7347 (1737). 
remoteness made it difficult, if not impossible, for the center and even the governors - assuming they were honest themselves - to restrain the arbitrary and corrupt behavior of their local agents, who could only find encouragement in the old injunction of the Muscovite government to operate « at your discretion and as God will inspire you. » ${ }^{27}$ With the passage of time, as military factors became increasingly important in the management of border regions and the actions of officials could have serious consequences for the peace and security of their territory, the imperial government began to grapple with the intractable issue of regional administration, pitting advocates of centralization and uniformity against those who felt that the administration of the borderlands ought to be given greater autonomy than that of the Russian core - an issue that would continue to plague the imperial government until its demise in 1917. ${ }^{28}$

Governor Dolgorukov's successor in Tobolsk, Alexei Pleshcheev, had been Governor Cherkasskii's deputy (tovarishch), then governor of Moscow and senator until 1730, when, perhaps out of fear, he sided with the opponents of autocratic rule. His «reward» was the Siberian governorship. He was recalled in 1736 following a denunciation that he had collected bribes, became president of the Siberian Chancery in 1740, and died in $1741 .{ }^{29}$ His successor, Petr Buturlin, had been a voevoda in Ufa: he held the modest rank of brigadier (class five in the Table of Ranks), while Cherkasskii had been a privy councillor (class three, the equivalent of a lieutenant general). He remained in Tobolsk until 1741. By then, the Senate had already concluded that the remoteness of Siberia was a cause of « confusion and disorder, » and that corruption was so widespread that it threatened the interests of the treasury. It recommended the appointment of Major General Ivan Shipov to be governor of Siberia in Tobolsk, because the government needed there « an honorable, intelligent, hard-working, and God-fearing man."30 Shipov had served in Peter's Persian campaign and on the left-bank Ukraine. From there, he was summoned to Petersburg in September 1740 to receive an instruction for the administration of Siberia. The instruction had been drafted by Pleshcheev and harked back to that given in 1697 to the Tobolsk voevoda, Petr Cherkasskii, brother of the future governor. ${ }^{31}$

A draft of Pleshcheev's instruction in 136 articles was considerably shortened by leaving out separate provisions for Irkutsk provintsiia. The Senate, which had divided Siberia into two provinces by appointing a vice-governor in Irkutsk in 1736, now insisted on retaining the administrative unity of Siberia under the

27. Istoriia Buriatskoi ASSR, vol. 1-2 (Ulan-Ude, 1954-1959), here vol. 1, 102.

28. I have discussed this large issue in J. Le Donne, "Russian Governors General, 1775-1825. Territorial or Functional Administration?” Cahiers du Monde russe, 42, 1 (2001): 5-30.

29. $R B S$, vol. 14 (1905) : 95-96

30. PSZ, vol. 11 (1830), N. 8218 (1740).

31. Ludmila S. Rafienko, "Instruktsiia Sibirskomu gubernatoru 1741g.," Arkheograficheskii Ezhegodnik (1973): 58-67, and Senatskii Arkhiv, vol. 1-15 (SPb., 1888-1913), here vol. 2 (1889), 369-372, and vol. 3 (1890), 345-347. 
Tobolsk governor. But nothing else was new, and the Senate's instruction suffered from the usual reluctance of the imperial government to give its regional delegates a set of specific powers. It merely gave him the usual universal jurisdiction over the levying of recruits for the College of War, the supervision of the collection of the revenue by agencies that were not dependent on him, and the administration of justice. Shipov sensed that much was expected of him but little was given to enable him to carry out the government's intentions. He asked to be subordinated, not to the Siberian Chancery, but to the Senate directly: this alone would give the Siberian governor a status higher than that of other governors who, as a rule, were subordinated to the colleges and not to the Senate. This request was refused. On the other hand, he obtained the retention of a vice-governor in Tobolsk, so that he could become a kind of governor general of Siberia, with two immediate subordinates, one in Tobolsk, the other in Irkutsk. ${ }^{32}$

Shipov was given very little time to make his mark in Tobolsk, let alone in Siberia. He was recalled in 1742 after the accession of Elizabeth and replaced by the Tobolsk vice-governor, Major General Alexei Sukharev, who would remain in Siberia for over ten years, despite the fact that his name surfaced a number of times in connection with investigations of corruption. ${ }^{33}$ However, he was followed by more respectable types like Lt.-Gen. Vasilii Miatlev (1753-1757), former quartermaster (ober-intendant) of the Baltic fleet, and Privy Councillor Fedor Soimonov (1757-1763). Both had made their career in the navy. Soimonov had grievously suffered from the knout and the ablation of his nostrils for his involvement in the Volynskii conspiracy of 1740 and had been sent to Okhotsk. Miatlev used him to investigate the navigation channel of the Shilka and the Amur in 1753 at a time of renewed interest in opening up the Amur to Russian boats seeking a better exit than Okhotsk to the sea of that name and the Pacific. ${ }^{34}$

There were other good reasons for sending higher-ranking delegates of the imperial government to Tobolsk in the 1750s. There was continued turbulence in the Kazakh steppe following the assassination of Abul Khair, the khan of the Western Horde, in 1748, and Chinese-Zunghar relations were worsening until the Manchu onslaught of 1756 destroyed the khanate and brought Chinese troops into the Kazakh steppe and Central Asia. Rumors of possible conflict with China were circulating. ${ }^{35}$ Russian ambitions in the Amur valley kept reminding the Manchu

32. Rafienko, "Instruktsiia Sibirskomu gubernatoru 1741g.," 59-60.

33. Baranov, Opis' imennym Vysochaishim ukazam, vol. 2 N. 3787, 5301, 6953, 7667; vol. 3 N. 8055, 8280, 8904, 9349. Akishin, Rossiiskii absoliutizm, 243-249.

34. On Miatlev see Baranov, Opis', vol. 3 N. 10241, 10785, 10804, 10833. On Soimonov, see RBS, vol. 19 (1909), 44-48; Baranov, Opis', vol.3. N. 10804; and N. Pavlenko, Anna loannovna. Nemtsy pri dvore (M., 2002), 264-296.

35. Peter C. Perdue, China Marches West: the Qing Conquest of Central Eurasia (Cambridge, MA: Belknap Press of Harvard University Press, 2005), 270-289. On the rumors see "O pobege iz goroda Nerchinska v Kitaiskii gorod Argun katorzhnika Shul' gina i o vozvrashchenii ego kitaitsami 1754-1755gg.," Chteniia V Imperatorskom Obshchestve istorii i drevnosti Rossiiskikh pri Moskovskom Universitete (hereafter CHOID) (M.: 1846-1918), here 1905, kn. 4, 49-55. See also Kasymbaev, Gosudarstvennye deiateli, 77-78. 
dynasty that it was vulnerable there. In 1745, five more regiments of regular troops were sent to western Siberia following Zunghar inroads into Kazakh pastures, and Major General Christian Kindermann assumed command of the Siberian Line, its troops now forming a separate corps with its own commander, who resided in Tobolsk or in Omsk, when he was not on inspection trips along the line. This commander was no longer subordinated to the governor in Tobolsk, but was made his equal in the administrative hierarchy. ${ }^{36}$ The greater responsibilities and prestige of the governor required that he be given the rank of either privy councillor or lieutenant general. Nevertheless, the administration of Siberia was henceforth split among two high ranking officials: the governor, responsible for civilian affairs, including logistical support for the troops, and diplomatic relations with China; the commander of the Siberian corps, responsible for the security of the border and relations with the nomads, including trade at the checkpoints, responsibilities which overlapped here with those of the governor.

The last appointment before the great reforms of the 1780s was that of Major General (later full general) Denis Chicherin in $1763 .{ }^{37}$ He would remain in Tobolsk for seventeen years, the longest tenure of any Siberian governor. During that time, there were four commanders of the Siberian Line: Lt. Gens. Johann von Springer (1762-1771), Johann Clapier de Colongue (1771-1777), Ivan Bagration (17771779), and Nikolai Ogarev (1779-1785). ${ }^{38}$ In 1764, a new instruction strengthened the powers of the governors, including Chicherin, by giving them jurisdiction, and not just supervision, over the activities of functional agencies which had until then ignored the governor and reported directly to their central offices. The instruction sought to create a form of territorial administration coordinated, no longer in a central agency, but in the governor's office, as had been the case from 1708 to the later 1720s, and the Siberian Chancery was closed once again. ${ }^{39}$ Chicherin was both an indefatigable governor and a true satrap who lived in high style, but also settled the Baraba steppe and the Tobolsk-Irkutsk corridor through which the Siberian trail ran, thereby increasing strategic mobility between western and eastern Siberia and developing an agricultural base to support the growing number of garrisons and Cossacks serving on the line. Also in 1764, Irkutsk provintsiia became a regular province (guberniia) with a governor, Wulf von Frauendorff, who had been vice-

36. Evgenii L. Besprozvannykh, Priamur'e $V$ sisteme russko-kitaiskikh otnoshenii. XVIIseredina XIX veka (M., 1983), 153-154. The two officers corresponded with "memoranda" (promemorii) used between agencies of equal standing: for an example see "Materialy dlia istorii Sibiri," CHOID (1866), kn. 4, 1-128, here 63-64.

37. On Chicherin see RBS, vol. 22 (1905), 427-429; K. Gazevinkel', "Sibirskii gubernator D. I. Chicherin," Istoricheskii Vestnik, no. 2 (April-June 1893): 783-790; N. Leskov, "Sibirskie kartinki XVIII veka," Vestnik Evropy, no. 4 (1893): 534-561, here: 547-552. On Chicherin and other Siberian governors see S. Shteingel', "Sibirskie satrapy 1765-1819," Istoricheskii Vestnik, no. 3 (July-Sept. 1884): 366-386.

38. Erik Amburger, Geschichte der Behördenorganisation Russlands vom Peter dem Grossen bis 1917(Leiden: E. J. Brill, 1966), 406.

39. J. Le Donne, "The Evolution of the Governor's Office, 1727-64," Canadian-American Slavic Studies, 12 (1978): 86-115. 
governor there since 1753.40 The distinction between western and eastern Siberia was now officially recognized, but while Chicherin's authority had been raised in Tobolsk, it no longer included eastern Siberia, and relations with China were vested in the Irkutsk governor in 1770.

No such division of authority between civilian and military commanders developed in the Orenburg Territory. Privy Councillor Ivan Nepliuev succeeded Urusov in 1742. His background was unusual for a regional delegate on the empire's periphery. He had been Russia's envoy (« resident») in Constantinople for fourteen years (1721-1735) and a strong proponent of making war on the Ottoman Empire, which he felt had reached its terminal stage. He had risen under Peter I, but owed his career under Anna Ivanovna to Ostermann's patronage. As a result he found himself in 1742 on the wrong side of the Court's politics. His appointment to the distant wilderness of Orenburg was, like that of Soimonov, a form of banishment, but also gave him a chance to make a great name for himself. ${ }^{41}$ In March 1744, the territory governed by the Orenburg Commission became Orenburg province and Nepliuev its first governor with full civil and military powers over regular and irregular troops - even though he was a civilian Russians and Bashkirs, the collection of taxes, the administration of justice, and relations with the Kazakhs. The provintsiia voevody in Ufa and Cheliabinsk were subordinated to him. ${ }^{42} \mathrm{He}$ would remain in Orenburg for sixteen years. Nepliuev encouraged the development of military settlements in Bashkiria and along the Orenburg Line, a policy which became a factor in the outbreak of another Bashkir rebellion in 1754-1755. He also invited Kazan Tatars to live in Orenburg and trade with the Kazakhs, and pursued a forward policy in the Kazakh steppe to accelerate the on-going disintegration of the khan's power in the Western and Central Hordes. The fact that Nepliuev resided in Orenburg (and possessed a forceful personality) required the combination of civil and military power in his office, while in western Siberia Tobolsk and Omsk were too far apart to make such a combination realistic for the time being.

Personality combined with a military command conferred great influence among the nomads, who were warriors themselves. When Real State Councillor (class four, the equivalent of a major general) Dmitrii Volkov was sent to Orenburg in 1763 - his appointment was also a form of banishment - he protested that he was not the right person for the job. Nepliuev, he wrote, would not have been so successful if he had not been a commanding general (glavnyi komandir) as well. Without a military command, the governor was certain to be despised both by the local population (largely military people) and the Kazakhs, who would feel he was

40. PSZ, vol. 16 (1830), N. 12269 (1764).

41. Vladimir N. Vitevskii, I. I. Nepliuev i Orenburgskii krai v prezhnem ego sostave do 1758 , vol. 1-4 (Kazan: 1897), here, vol. 1, 106-117. See also Zapiski Ivana Ivanovicha Nepliueva (1693-1773) (SPb., 1893), 133-165.

42. PSZ, vol. 12 (1830), N. 8901 (1744). The Orenburg Territory was at first administered by the Orenburg Expedition, renamed Commission in 1738, and the provincial chancery from 1744 . 
somebody else's man (pod opekoi). A divided command caused misunderstandings and resulted in needless correspondence. The governor must have an imposing appearance (vazhnyi vid) to impress Bashkirs and Kazakhs; he, Volkov, did not have one, and he did not own a carriage. ${ }^{43}$ The empress agreed, and recalled Volkov in 1764. After a short interval, she appointed in 1768 Major General (promoted to lieutenant general in 1771) Johann von Reinsdorp who, like Chicherin in Tobolsk, would remain in Orenburg a long time: he died in office in 1781.

But even the unity of command did not guarantee security in a highly turbulent frontier. Reinsdorp complained about the sparsity of population, the lack of industry, and the low level of commercial exchanges. His first crisis came in 1771, when most of the Kalmyks, corralled between the Volga and the Ural river, crossed into the Kazakh steppe and escaped to Mongolia. Russians and Cossacks were caught by surprise and could not catch up with them. ${ }^{44}$ Although the flight of the Kalmyks removed an element of insecurity, it also exposed the weakness of the line and Cossack outposts, as well as the fact that much of the infrastructure of empire still rested on unstable foundations. ${ }^{45}$

The second crisis came in 1772. The Ural Cossacks, who had been placed under the jurisdiction of the Orenburg governor in 1744, had long been driven by internal dissensions which reached a climax that year. Rank-and-file Cossacks killed Major General von Trauenberg, who was sent by Reinsdorp to investigate the disorders, as well as their own ataman. The governor put down the rebellion in a brutal manner, but the following year a greater threat appeared in the form of the Pugachev rebellion, which rallied Cossacks, Old Believers, Polish confederates banished there in the 1760s, and Bashkirs. ${ }^{46}$ The rebels besieged Orenburg but could not take it. In retaliation, Reinsdorp contemplated the mass deportation of the Bashkirs, but the central government was not willing to go that far. But when the governor died, he had completed Nepliuev's work and consolidated imperial rule in Bashkiria.

The Russians' withdrawal behind the Terek in 1735 enhanced the importance of Astrakhan and explained the founding of Kizliar that same year. ${ }^{47}$ The assassination of Nadir Shah in 1747 removed a potential threat to Russia's ambitions in the

43. «Zapiski D. I. Volkova, » VIRGO, vol. 27 (1859): 49-60.

44. "Zapiska Orenburgskogo gubernatora Reinsdorfa o nedostatkakh v verennoi emu upravleniiu gubernii 1770g," VIRGO, vol. 27 (1859): 90-104; Courant, L'Asie centrale, 129131, 134-139; Ocherki istorii Kalmytskoi ASSR (M., 1967), 216-221; and V. Vitevskii "Iaitskoe voisko do poiavleniia Pugacheva," Russkii Arkhiv, vol. 3 (Sept.-Dec. 1879): 377-402 and 435-458, here: 393-398. On the exodus of 1771 see Michael Khodarkovsky, Where the Two Worlds Meet: The Russian State and the Kalmyk Nomads, 1600-1771 (Ithaca: University of Chicago, 1992), 224-35.

45. For an extensive discussion of this issue see PSZ, vol. 19 (1830), N. 13649 (1771).

46. For the Cossack revolt see Vitevskii, "Iaitskoe voisko," 435-458. On Reinsdorp in general and his role in putting down the rebellion see D. Mordovtsev, "Russkie gosudarstvennye deiateli proshlogo veka i Pugachev," Otechestvennye Zapiski (hereafter OZ), vol. 80 (Oct. 1868): 348-388, here: 367-369). On the Pugachev rebellion in general see John T. Alexander, Autocratic Politics in a National Crisis: the Imperial Russian Government and Pugachev's Revolt, 1773-1775 (Bloomington: Indiana University Press, 1969).

47. “Zapiski o Kizliare,” CHOID, 1861, kn. 4, 99-124, here 43-44. 
Caucasus, and the Kizliar commandant became the empire's most important link with the highlanders, not unlike the Selenginsk commandant with the Mongols and Chinese. He answered to the Astrakhan governor, his equal in the hierarchy, Major General Nikita Beketov (1763-1773). Beketov was followed by Major Generals Petr Krechetnikov (1773-1776) and Ivan Iakobi (1776-1781). The founding of Mozdok in 1763 was another stage in the building of the so-called Caucasian Line, completed in $1781.4^{48}$ It was a major enterprise stretching over 1000 kilometers, beyond Mozdok northwards to Azov and later westwards along the Kuban to its mouth on the Black Sea, bridging the entire isthmus between that sea and the Caspian and linking the eastern with the western theaters. By the 1780s, the empire had built a nearly uninterrupted perimeter linking the Crimea with the Altai.

The Caucasian Line became a separate command under Major Generals Johann von Medem (1763-1771), Johann von Brinck (1771-1777), and Alexander Suvorov (1777-1782), all of whom were subordinated to the College of War, but who probably also reported to the Astrakhan governor, as was the case in western Siberia. However, the rank of all these officers and Astrakhan governors shows that the Caucasus remained of secondary importance. Throughout this period, from the 1730 s to the 1780 s, the action took place in Bashkiria and in the Kazakh steppe, where lieutenant generals, members of the ruling elite as I understand it, ${ }^{49}$ were becoming by the 1760 s the true empire builders.

But the situation was about to change radically, and the Caucasus would eventually become the most important strategic sector in the eastern theater. In eastern Georgia, which had long been in Persia's sphere of influence, Nadir Shah had kept the country divided, but it was united in 1762 under Erekle II, who would rule until his death in 1798. Erekle needed Russian support to consolidate his rule against his fractious nobility and to recreate a Greater Georgia. As a result, he favored Russia's expedition of 1769 in Transcaucasia, only to discover that the Russians were beginning to look beyond the mountains in search of a strategic base from which to attack the Ottomans in western Georgia and were still uninterested in a forward strategy against Persia. ${ }^{50}$ In Caucasian Azerbaijan, nine semiindependent khanates arose on the ruins of Nadir Shah's empire, including that of Karabakh or much of eastern Armenia. These khanates were ruled by khans who were also tribal leaders and whose first loyalty was to their tribes and not to Persia, which itself was so internally weakened that it did not even have its own shah. The politics of that tribal elite was the politics of plunder, unchecked by any higher power. ${ }^{51}$ Erekle's ambitions, unrest in the mountains, and political disintegration

48. Iosif Debu, "O nachal'nom ustanovlenii i rasprostranenii Kavkazskoi linii," $O Z$, vol. 16 (1823), 234-248; vol. 18 (1824), 268-293; and vol. 19 (1824), 48-74.

49. Le Donne, Absolutism and Ruling Class, 4.

50. David M. Lang, The Last Years of the Georgian Monarchy 1658-1832 (New York: Columbia University Press, 1957), 94.

51. Audrey Alstadt, The Azerbaijani Turks: Power and Identity under Russian Rule (Stanford: Hoover Institution Press, 1992), 9-10; Istoriia Azerbaidzhana, vol. 1-3 (Baku 1958-1963), here vol. 1, 334-351. 
combined to create a turbulence that imperceptibly invited the Russian advance, in much the same way as the growing weakness of the Kazakh khans of the Western and Central Hordes was drawing the Russians into Kazakh politics and helped them consolidate their power all along their military periphery.

On the eve of the administrative reform of the 1780s, which transformed the map and created a system that would basically remain unchanged until the Revolution, the eastern theater consisted of five provinces (Astrakhan, Kazan, Orenburg, «Siberian,» or Tobolsk, and Irkutsk) divided into 48 uezdy administered by voevody. Eighteen of the 48 were in Kazan province divided into six provintsii, including that of the provincial capital (Kazan, Viatka, Perm, Sviiazhsk, Simbirsk, and Penza) and another 14 were in Irkutsk province. The Kazan-Orenburg region contained 24 uezdy and Siberia 21. The other three were in Astrakhan province.

There had been very few changes since $1727 . .^{52}$ In Orenburg alone was the governor also a commanding general. In Astrakhan and western Siberia the governor, even if he was a general, had to share the administration of his province with a general of equal rank, whose responsibilities were chiefly military, but who also played a crucial role in Russia's relations with the nomads in the frontier, one that was bound to grow, as those relations became more complex and increasingly involved contacts with other core area powers, like Persia and China.

According to the figures for the 1782 census, the population of the eastern theater numbered 6.3 million people (both sexes), including 3.9 in Kazan province, 588,000 in Orenburg province, and 1 million in Siberia, with another 825,000 in Astrakhan province. Everywhere, except in Orenburg, the Russians formed a majority: 73.6 percent in Kazan province, 67.6 percent in Siberia, 54.2 percent in Astrakhan. In Orenburg alone, they were still a minority of 37.2 percent, largely a consequence of the bloody Bashkir rebellions of 1735-1741 and 1754-1756 and the Pugachev rebellion, which had slowed the influx of Russian peasants and landowners. The largest group of non-Russians was the Tatars in Astrakhan, Tatars and Chuvash in Kazan province, the Bashkirs in Orenburg province, the Buriats and Yakuts in Siberia. The largest group of nomads, not included in the 6.3 million, was the Kazakhs, whose number was unknown at the time but may have exceeded one million. Altogether, this population of 6.3 million represented only 17.2 percent of a total population of 36.6 million in the empire, among whom the Russians made up 49.1 percent or 18 million. ${ }^{53}$

52. Got'e, Istoriia oblastnogo upravleniia, 124.

53. Vladimir Kabuzan, Narody Rossii V XVIII veke: Chislennost' i etnicheskii sostav (M.: Nauka, 1990), 226-228, 230. For Siberia see also V. Kabuzan and S. Troitskii, "Dvizhenie naseleniia Sibiri v XVIII v.," Materialy po istorii Sibiri. Sibir' V XVII-XVIII VV. (Novosibirsk, 1962), 139-157. Nolde uses the striking expression: "la marée montante des Russes" (the rising Russian tide) when discussing the progress of Russian colonization: La Formation, vol. 1, 171. 
The consolidation of Russia's imperial infrastructure in the eastern theater took place in three stages during the next period, from the 1780s to the 1840s. During Catherine's reign, the administrative-territorial reform, which affected both the Russian core and the outlying regions in all three theaters, broke up the largest provinces and uezdy into smaller ones in accordance with a uniform quantitative criterion. The result was the near abolition of the distinction between core and periphery and the creation, from an administrative point of view, of a unitary state. Not only was the number of provinces and uezdy considerably increased at each level, but the size of the administrative staff nearly trebled, in one of the most massive redistribution of the spoils in Russian administrative history.

In the eastern theater, this reform was implemented between 1780 and 1785. The number of provinces rose from five to eleven and the number of uezdy from 48 to 138. Kazan province was divided into five new provinces including Kazan (Viatka, Perm, Simbirsk and Penza) with 68 uezdy, where there had been only 18. Astrakhan province disappeared to become Saratov province and the province of Caucasus, the latter divided into two oblasti - a new name for the old provintsiia which, however, was abolished almost everywhere else - Caucasus, with its capital in Ekaterinograd, and Astrakhan. The number of uezdy rose from three to nineteen. Orenburg province was divided into thirteen uezdy instead of six, and two oblasti in Ufa and Orenburg. In Siberia, the changes were less significant.

There were now three provinces: Tobolsk, with two oblasti (Tobolsk and Tomsk) and 16 uezdy; Kolyvan with five uezdy; and Irkutsk with four oblasti (Irkutsk, Nerchinsk, Yakutsk and Nerchinsk) and 17 uezdy, a total of 38 uezdy, instead of 21 in 1774. Each province remained headed by a governor, usually in the rank of major general, but the provincial chancery, under the name of provincial board, was now only one of four agencies, with a treasury, a civil and a criminal court, duplicated at the uezd level in the form of a land court, a uezd court (civil and criminal), and a treasury. But two or more provinces were now combined under a governor general, who was either a lieutenant general or a full general, directly responsible to the empress, the procurator general as the head of the civil administration, and the president of the College of War. In Orenburg province, ${ }^{54}$ the capital was moved « inland » to Ufa, more centrally located. Its southern part, Orenburg oblast', was placed under a senior (ober) commandant in the rank of major general, creating a situation analogous to that prevailing in the Caucasus and western Siberia, even though the distance between Orenburg and Ufa was only 333 kilometers, while Georgievsk was about 500 kilometers from Astrakhan and Omsk 1700 from Tobolsk. Since the situation was new there, it created « misunderstandings. » Major General

54. J. Le Donne, "The Territorial Reform of the Russian Empire 1775-1796. II. The Borderlands 1777-1796," Cahiers du Monde russe et soviétique, 24, 4 (1983) : 411-457, and J. Le Donne, Ruling Russia. Politics and Administration in the Age of Absolutism 1762-1796 (Princeton: Princeton University Press, 1984), 79. 
Yakov Zembulatov in Orenburg refused to recognize the governor in Ufa as his superior, although existing law made it clear that commandants were subordinated to the governor, as the Senate insisted in 1786. Of course, both were subordinated to the governor general of Simbirsk and Ufa, Lt.-Gen. Otto (Osip) von Igelstrom (17841791), who originally resided in Simbirsk. ${ }^{55}$

Linking Ufa with Simbirsk marked a significant departure in the spatial orientation of Russia's imperial administration. Until the reform, the perception of the periphery had been a fragmented one, and it always looked south, along the axis of the Russian advance: from Astrakhan to the Terek, from Kazan to Orenburg, from Tobolsk to Omsk and the Altai, from Irkutsk to Selenginsk and Kiakhta. The reform looked upon the frontier as a continuous expanse stretching eastwards across the entire eastern theater from the Terek to the Argun, with four military command centers, in Georgievsk for the Caucasus, Simbirsk/Orenburg, Omsk and Irkutsk for Siberia.

Linking Simbirsk with Ufa was historically justified. The fortified lines in Orenburg province had been an extension of the Simbirsk Line, and Simbirsk was the crossing point for travellers to and from Bashkiria. In Siberia, Tobolsk province was linked with the new Perm province under a governor general. It was the first time since 1728 - when the center's perspective on the frontier still followed a primarily west-east axis - that the western and eastern slopes of the Urals were joined with the Siberian plain under a single administrative authority. Two governors general were appointed in Tobolsk: Lt. Gens. Evgenii Kashkin (17801788) and Alexei Volkov (1789-1797). ${ }^{56}$ The reform placed the industry of the northern Urals with its labor force, among which were many Old Believers, under the Perm treasury chamber. Perm on the Kama, near the confluence of the Chusovaia, which crossed the entire chain, was better situated than Ekaterinburg which had always faced east, toward Siberia. Perm, like Simbirsk, was a transit point from which barges loaded with salt and iron descended the Kama toward Kazan and Nizhnii Novgorod; it was also a point of entry into Siberia via Kungur.

The emergence of Perm and the Tobolsk-Perm combination accelerated the decline of Tobolsk that followed the creation of a military command on the line and the development of the Irbit fair, as well as of Petropavlovsk and Semipalatinsk, as trade centers on the edge of Kazakh country. ${ }^{57}$ The decline of Tobolsk entailed the rise of Omsk, the headquarters of the Siberian Line, forming a continuous fortified perimeter from the Volga to the Saian Mountains. The major

55. PSZ, vol. 22 (1830), N. 16368 (1986). On Igelstrom see RBS, vol. 8 (1897), 43-44; "Arkhiv grafa Igel'stroma," Russkii Arkhiv, no. 6, (1886): 341-371, 480-497; and P. Iudin, "Baron O. A. Igel'strom v Orenburgskom krae," Russkii Arkhiv, no. 3 (1900): 383-401. For a detailed study of the administration of the Orenburg Territory see N. Semenova, "Voennoe upravlenie Orenburgskim kraem v kontse XVIII-pervoi polovine XIX vv," Kandidat diss. (Orenburg, 2000). I thank Kimitaka Matsuzato for giving me a copy of the dissertation.

56. On Kashkin see RBS, vol. 8 (1897), 585-587 and P. Petrov, "Evgenii Petrovich Kashkin 1737-1796," Russkaia Starina, no. 3, (July-Sept. 1882): 1-40.

57. Jan Potocki - writing in 1805 - called Tobolsk "une ville en décadence": Voyages, Daniel Beauvois, ed., vol. 1-2, (P. : Fayard, 1980), here vol. 2, 191 
figure there was Lt.-Gen. Gustav von Strandmann (1787-1798), ${ }^{58}$ a Baltic nobleman like Igelstrom, both proponents of a forward policy, one against the Kazakhs, the other against the Chinese in Mongolia, only waiting to be coordinated with that of their colleague in Irkutsk, Lt.-Gen. Jakobi. In other words, the administrative integration of the frontier under three military commands along a west-east axis was paving the way for a resumption of the Russian advance toward the south, into the Kazakh steppe and toward the Lake Zaisan depression, in the direction of Central Asia and eastern Turkestan (the future Sinkiang).

In eastern Siberia, Irkutsk and Kolyvan provinces were combined under a governor general in Irkutsk, lakobi between 1783 and 1787, and Lt.-Gen. Ivan Piel (1789-1795). As a result, the Altai gold mining district — placed in 1747 under the Cabinet and removed from the jurisdiction of the civilian administration but now combined under the treasury chamber - and the Nerchinsk silver mines were placed under a single authority; so was the entire mountainous region from the Irtysh to the Sea of Okhotsk, facing Mongolia and the Amur basin, the last segment of that immense frontier following a west-east axis, but also facing outward. It was no coincidence that Jakobi was recalled on suspicion - not entirely unjustified that he was planning to wage a war on China, and that Piel sent an expedition to Japan to negotiate the opening of the country to Russian trade and warships. ${ }^{59}$

The administrative restructuring of the Astrakhan-Caucasian sector introduces us to the development of Catherine's reforms during the second stage, from 1796 to the reform of 1822 . The creation of Saratov province in 1780 finally ended the old marginalization of the city as the northern outpost of distant Astrakhan. Five years later, a Caucasian province incorporated the eastern steppe of the northern Caucasus and the lower Volga depression below Tsaritsyn. Its capital, Ekaterinograd - a new «city » at the confluence of the Malka and the Terek, upriver from Mozdok - lasted until 1790, when Astrakhan became a provincial capital once again. ${ }^{60}$ The province was linked with Saratov under Lt.-Gen. Pavel Potemkin (1784-1792), but was later combined with Riazan and Tambov under General Ivan Gudovich. ${ }^{61}$ Both governors general were commanding generals on the line. The Caucasus thus represented an exception to the pattern of a west-east administrative-military frontier. Especially under Gudovich, it formed the end of a corridor of expansion along a north-south axis running from Moscow straight to the Caucasus.

58. RBS, vol. 23 (1911), 437-439; G. Shtrandman, "Sibir' i eia nuzhdy v 1801 godu," Russkaia Starina, no. 1 (Jan.-April 1879): 150-156; and P. Iudin, "Kitai," Russkii Arkhiv, no. 3 (Sept.Oct. 1900): 151-160.

59. J. Le Donne, "Proconsular Ambitions on the Chinese Border: Governor General Iakobi's Proposal of War on China," Cahiers du Monde russe, 45, 1-2 (2004): 31-59. On the expedition to Japan see PSZ, vol. 23 (1830), N. 16985 (1791), and "Popytki k zavedeniiu torgovli Rossii s laponiei v 1791 godu," Russkaia Starina, no. 3 (July-Sept. 1896): 28-30.

60. PSZ, vol. 22 (1830), N. 16193 (1785); vol. 23 (1830), N. 16858 and 16898 (1790).

61. J. Le Donne, "Frontier Governors General 1772-1825. II. The Southern Frontier," Jahrbücher für Geschichte Osteuropas, vol. 48 (2000): 161-183, here: 175-176. 
But not a dead end, because political developments at the turn of the century were about to raise the importance of the Caucasian sector vis-à-vis Orenburg and Omsk. The accession of Paul in November 1796 brought about the elimination of the post of governor general: the tsar did not like intermediate authorities at the regional level between himself and the provincial governors, although he also favored larger provinces in the borderlands that would maintain a certain continuity with the preannexation territories. Governors general were replaced by military governors with jurisdiction over a single province. Gudovich became military governor of a larger Astrakhan province (1796-1800), and was succeeded by Lt.-Gen. Karl von Knorring. ${ }^{62}$ At this juncture, Erekle's son and successor, Georgii XII, offered to place eastern Georgia under the tsar's scepter, and the offer was accepted in $1801 .{ }^{63}$ The new commitment, accepted only reluctantly, to deploy forces in Transcaucasia and integrate the territory into the administrative structure of the empire, resulted in the creation of three provinces in 1802: Astrakhan, Caucasian, and Georgian, with capitals in Astrakhan, Georgievsk (on a tributary of the Kuma), and Tiflis (on the Kura). It was inevitable that such a vast and complex region of interconnected parts would require the recreation of a regional authority. In 1802, Lt.-Gen. Pavel Tsitsianov was appointed Chief Administrator (glavnoupravliaiushchii) in Georgia, military governor in Georgievsk and Astrakhan, and commanding general of regular and irregular troops on the line and in Georgia. Beginning in 1811, these troops constituted the Georgian Corps, renamed Caucasian Corps in 1820.64

Tsitsianov had barely settled down in Tiflis when Russia and Persia went to war. Tensions had grown since the founding of the Qajar dynasty by Aga Mohammed Khan, who devastated eastern Georgia in 1795, prompting a reawakening of Russia's interest in Transcaucasia. The war continued intermittently for nine years and ended in 1813 with the Treaty of Gulistan: Russia annexed the khanates of Ganzha (renamed Elizavetpol), which became a uezd capital of the province of Georgia), Karabakh, Shirvan, Derbent, Kuba, Baku, and part of Talysh, and gained the exclusive right to navigate warships on the Caspian.65 A new commanding general and chief administrator - a de facto governor general - arrived in 1816: Lt.-Gen. Alexei Ermolov, whose controversial tenure nevertheless strengthened Russian rule in the Caucasus. ${ }^{66}$

62. To trace the appointment of governors and governors general a very useful source is Gubernii Rossiiskoi imperii. Istoriia i rukovoditeli 1708-1917(M., 2003).

63. Lang, "Last Years," 226-232; Nolde, La Formation, vol. 2, 370-84.

64. PSZ, vol. 27(1830), N. 20511 (1802); vol. 31(1830), N. 24715 (1811), and vol. 37 (1830), N. $28436(1820)$.

65. Jacob C. Hurewitz, ed., The Middle East and North Africa in World Politics. A Documentary Record, 2nd ed. vol. 1-2 (New Haven: Yale University Press, 1975-1979), here vol. 1, 197-199. Russian text in PSZ, 32 (1830), N. 25466 (1813). See also Muriel Atkin, Russia and Iran, 1780-1828 (Minneapolis: University of Minnesota Press, 1980), 84-90 and Istoriia Azerbaidzhana, vol. 2, 1-20.

66. Nikolai F. Dubrovin, “Aleksei Petrovich Ermolov na Kavkaz,” Voennyi Sbornik, 1882, 1884 , and 1886 (15 articles). 
Hardly any change took place in Orenburg: the province was placed under a military governor who also commanded the troops on the line forming the Orenburg Corps beginning in 1815. The administration of Siberia, however, continued to preoccupy the imperial government, which hesitated between three options. One was to appoint a military governor, who would also command the troops on the line, and remove the provincial agencies to Omsk. This was not retained because Omsk, despite its growing strategic importance, was still a frontier outpost without the physical infrastructure necessary for a provincial and regional capital, while Tobolsk had long been the «capital of Siberia. » Another was to divide Siberia into provinces and administer the region as an extension of the Russian core. That was not practical, because Siberia was too large and too remote, and governors were not authoritative enough. The third was to appoint a governor general for the entire territory.

This third option won the government's support. A military governor was appointed in Irkutsk who remained until 1803, while Tobolsk had a mere governor. Kolyvan province was abolished and reintegrated into Tomsk uezd of Tobolsk province. But in 1804, Tobolsk province was divided into two, Tobolsk and Tomsk, with the appointment of Lt.-Gen. Ivan Selifontov as governor general for the three provinces, Tobolsk, Tomsk, and Irkutsk - the only region where the post was officially recognized. He was given extensive powers, including the command of all troops in the territory and even the right to change their deployment. This may have never been carried out, however, as we learn from the reservation expressed by the war minister when Selifontov's successor, State Councillor Johann Pestel, was appointed in $1806 .{ }^{67}$ Pestel's tenure was unusual: after a short trip to Siberia he returned to Petersburg, where he remained until his dismissal in 1819. It amounted to the recreation of the Siberian Chancery, abolished in 1763: the management of a large territory was concentrated, not in a regional authority, but in one residing in the capital. ${ }^{68}$

The many complaints emanating from Siberia against abuses committed by provincial officials resulted in the appointment of Privy Councillor Mikhail Speranskii as governor general in 1819, with a mission to reorganize the administration of Siberia from top to bottom. Thus began the third stage in the consolidation of Russia's rule in the eastern theater. The product of Speranskii's labor was twelve statutes, reviewed by the Siberian Committee created in July 1821, and approved by the emperor in July $1822 .{ }^{69}$ The Committee, which

67. PSZ, vol. 27 (1830), N. 20771 (1803); vol. 29 (1830), N. 22143 (1806); vol. 31 (1830), N. 24331 (1810).

68. On Selifontov and Pestel see J. Le Donne, "Frontier Governors General. III. The Eastern Frontier,” Jahrbücher für Geschichte Osteuropas, vol. 48 (2000): 321-340, here: 330-331.

69. The twelve statutes were published in PSZ, vol. 38 (1830), N. 29125-29136 (1822). On the Siberian Committee see the short entry in Russkaia Starina, no. 2 (April-June 1903): 624. A general survey of the reforms is Marc Raeff, Siberia and the Reforms of 1822 (Seattle: University of Washington Press, 1956). For an attempt to place them in an all-imperial context see I. Dameshek, ed., M. M. Speranskii: Sibriskii variant imperskogo regionalizma (Irkutsk, 
remained in existence until 1838, was in fact a kind of subcommittee of the Council of Ministers, much in the same way as the Siberian Chancery had been a committee of the Senate. Old habits die hard.

The reform divided Siberia into two regions. Western Siberia consisted of two provinces (Tobolsk and Tomsk), and Eastern Siberia of another two (Eniseisk and Irkutsk). Omsk formed a separate oblast' under a de facto military governor. Eastern Siberia included Yakutsk oblast”, two «coastal administrations » in Okhotsk and Kamchatka, and one border administration at Troitskosavsk near the Mongolian border. These separate agencies reported to the Irkutsk governor.

Two governors general were appointed, one in Tobolsk, the other in Irkutsk: Lt.Gens. Petr Kapsevich (1822-1827), who commanded the Siberian Corps in Tobolsk, Alexander Lavinskii (1822-1833), who had been governor in Vilna (1811-1814), in Irkutsk. ${ }^{70}$ Siberia thus remained a single military district, but divided into two administrative regions. However, there remained something awkward in requiring the governor general to reside in Tobolsk. In 1825, Kapsevich moved to Omsk, thereby uniting civilian authority and military command for the first time since 1745; he left a civil governor in Tobolsk. By the mid-1820s, the infrastructure of empire had taken final shape in the eastern theater. Its two pillars were the Caucasus and western Siberia, and its capstone was Orenburg province. Eastern Siberia would remain a forlorn region until the opening of China by the British in the 1840s revolutionized the geopolitical situation in the Far East, and the annexation of the Amur valley and the Maritime Province in 1860 created a third pillar with a second capstone in Irkutsk.

The systematic reform of the Siberian administration created a momentum to carry out a similar reform in the Caucasus. In February 1827, the Siberian Statute ${ }^{71}$ was extended with some modification to the northern Caucasus, but the time was not opportune: Russia was at war with Persia once again (1826-1828). In 1824, the title of khan had been abolished in Sheki, Shirvan, and Karabakh, and the khanates became small provintsii administered by a commandant subordinated to a de facto military governor. This type of administration was a fiasco and became a scandal: it gave arbitrary power to military personnel unchecked by the « governor general » in Tiflis, who looked upon Transcaucasia as a zone of occupation, what with the growing unrest in the mountains and chronic tensions with Persia. ${ }^{72}$ By the Treaty of Turkmanchai (1828) Russia annexed the khanates of Erivan and Nakhichevan, combined to form an Armenian oblast ${ }^{\prime}$ under military administration. ${ }^{73}$

2003), 160-61. See also J. Le Donne, "Regionalism and Constitutional Reform 1819-1826," Cahiers du Monde russe, 44, 1 (2003): 5-34, here: 19-22.

70. J. Le Donne, “The Eastern Frontier,” 333.

71. PSZ, vol. 2 (1830), N. 878 (1827). I mean here the first of the twelve statutes dealing with regional, provincial, and local agencies: N. 29125.

72. PSZ, vol. 39 (1830), N.30516 (1824). A. Mil'man, Politicheskii stroi Azerbaidzhana V XIXnachale XX vekov (Baku, 1966), 67-70, 102-103. See also Dubrovin, "Aleksei Petrovich Ermolov," Voennyi Sbornik, no. 2 (1882): 205-240, here: 234-235, and Atkin, Russia and Iran, 145-149.

73. Hurewitz, vol. 1,232-237; Russian text in PSZ,3, 1794 (1830) and 1888 (1828) 
Twelve years later, in 1840, the imperial government, determined to normalize the situation in Transcaucasia, extended the Siberian Statute to that region as well, with the chief administrator in Tiflis - who also commanded the Caucasian Corps - responsible for civil and military affairs and relations with Persia as well as with the various native groups on both sides of the mountains. He was assisted by a military governor in Tiflis. Transcaucasia was divided into three major territories: Georgia-Imeretia province, which combined most of the Georgian lands in both eastern and western Georgia; a Caspian oblast', its capital in Shemakha, encompassing the Shi'ite Turkic provintsii, except Derbent and Baku, which formed a separate military district; and the Armenian oblast'. One suspects the influence of Speranskii behind this policy of administrative unification across the entire eastern theater: he was the author of the Siberian Statute and the official responsible for the codification of the empire's laws until his death in $1839 . .^{74}$

And yet, such a policy was forced because it did not take into account that Siberia and the Caucasus were moving into opposite directions. Siberia was becoming a sector of relative peace, while the Caucasus was becoming a war zone, with over 50,000 troops deployed there in $1816^{75}$ - and many more to come - while all regular troops had been withdrawn from Siberia in 1808. In 1842, a Caucasian Committee was created in Petersburg, like the Siberian Committee which had recently been closed, a subcommittee of the Committee of Ministers. In 1844, the post of chief administrator was replaced by that of viceroy (namestnik), similar to the post of viceroy in Warsaw, an exceptional innovation in Russian administrative history. Its first occupant was General Mikhail Vorontsov, who had been governor general of New Russia since 1822. Instead of integrating the region more deeply into the empire, as General Ivan Paskevich, Ermolov's successor (1827-1831), intended in $1830^{76}$, the reform set it apart as a quasi-independent territory, the viceroy being responsible to the tsar alone. In 1846, Transcaucasia was divided into four provinces (Tiflis, Kutais, Shemakha, and Derbent), the Armenian oblast' became Erevan province in 1850, and Shemakha province was renamed Baku province in 1859. In this basic outline, the administration of the Caucasus remained unchanged until the abolition of the post of viceroy in 1881 and the closing of the Caucasian Committee the following year. ${ }^{77}$

74. PSZ, 15 (1841), N. 13368 (1840). Curiously enough, Milman in his examination of the 1840 statute completely overlooks the similarities with the Siberian statute: Mil'man, Politicheskii stroi, 108-117.

75. M. Bogdanovich, Istoriia tsarstvovaniia Imperatora Aleksandra II Rossii v ego vremia, vol. 1-6 (SPb., 1869-1871), here vol. 5, Annex, 41-42.

76. Mil'man, Politicheskii stroi, 105; M. Rozhkova, "Iz istorii ekonomicheskoi politiki rossiiskogo tsarizma v Zakavkaz'e (pervaia polovina XIX v.)," Istoricheskie Zapiski, 18 (1946): 169-200, here: 186-87. For other similar recommendations see Aleksandr P. Shcherbatov, General-fel'dmarshal Paskievich, Ego zhizn' I deiatel'nost', 7 vol. (SPb., 1888-1904), here vol. 3 (1891), annexes, 122-27, 134-35. The full text of Paskievich's report is in Akty sobrannye Kavkazkoiu Arkheograficheskoiu Kommissieiu (Tiflis, 1866-1904), here vol. 7, 35-39.

77. To follow the changes in the administration of the region see V. Ivanenko, Grazhdanskoe upravlenie Zakavkaz'em ot prisoedineniia Gruzii do namestnichestva vel. kn. Mikhaila Nikolaevicha (Tiflis, 1901), here 119-160, 225-254. See also Semen Esadze, ed., Istoricheskaia zapiska ob upravlenii Kavkazom, 2 vol. (Tiflis, 1907), here vol. 1, 29-68. 
By the 1840 s, the eastern theater consisted of 16 provinces (instead of 11 in 1796), divided into 135 uezdy as the basic administrative unit with its police agency, court, and treasury, or three less than in $1796 .{ }^{78}$ Sixty-eight were in the old Kazan region, including 15 in Orenburg province, 30 in Siberia, and 37 in the Caucasus, including 19 in the Lower Volga region (Saratov, Astrakhan, and northern Caucasus). In this enormous territory, now stretching from the Turkish and Persian border to Kamchatka on the Pacific, the population had grown, according to the 1833 census, to 16.5 million people, up from 6.3 million in 1782 , of whom 9 million or 54 percent were Russians. As in 1782, the Russians formed a majority everywhere except in Bashkiria, where they remained a minority of 49 percent (up from 37.2 percent). In the Kazan region and in Siberia, they made up 73.1 and 73.7 percent of the population, in the Lower Volga region 65 percent. Only in Transcaucasia were they almost totally absent (less than 1 percent). The two large blocks were the Kazan region with 8.3 million people (including 1.7 million in Orenburg province), and the Lower Volga with the Caucasus with nearly 6 million. The population of Siberia had more than doubled since 1782 but did not exceed 2.3 million. Everywhere in the triptych, the population remained highly diversified from an ethnic point of view. Altogether the population of the eastern theater made up 26 percent (up from 17.2 percent) of the empire's total population of 63.2 million, among whom the Russians made up 45.3 percent (down from 49.1 percent), or 28.6 million. ${ }^{79}$

Russia's conquest of the khanates of Kazan, Astrakhan and Sibir' in the sixteenth century, and its subsequent rapid expansion across Siberia, created a geopolitical theater in the form of a triptych resting on three strong points: Kazan in the center, Astrakhan in the south, and Tobolsk in the east, with Yakutsk, later Irkutsk, a fourth further east. The Russians had been recreating the Kipchak khanate but under Moscow's leadership, a core from which they could later carry out the reunification of the Mongol Empire (outside China) as far as the Zagros Mountains and the Hindu Kush. ${ }^{80}$ But huge distances, sparse population, and the slow progress of the settler into territory that had been dominated by the nomads for centuries created enormous obstacles to the construction of an infrastructure of empire that would consolidate Russian rule.

78. Of the 138 uezdy in 1796, there were 13 less in the Kazan-Orenburg region, 8 less in Siberia, and 18 new ones in Transcaucasia.

79. Vladimir Kabuzan, Narody Rossii v pervoi polovine XIX V. Chislennost' i etnicheskii sostav (M.: Nauka, 1992), 121-122, 124-125.

80. In March 1900, War Minister Aleksei Kuropatkin reported to Nicholas II that Russia must acquire "full political and economic hegemony (gospodstvo) over the whole of Persia to the Indian Ocean and the Persian Gulf," RGIA (Rossiiskii Gosudarstvennyi Istoricheskii Arkhiv), f. 1622, op. 1. d. 269. 11. 43 ob. I am grateful to David Schimmelpenninck van der Oye for letting me consult this document. 
The approach was conservative at first. Two central agencies and a network of local agents (voevody) created a basic administrative grid to implant a minimal Russian presence among native groups, who had paid the iasak (fur tax) to their nomad overlords and who now had to pay it to the Russians. Peter I, however, determined as he was to establish Russia as the hegemonic power in Eurasia, launched deep strikes into the river valleys of western Siberia and along the Caspian coast into northern Persia in an attempt to reach India and, in the process, transform Transcaucasia, Persia, and Central Asia, all former dependencies of the Mongol Empire, into Russian protectorates.

The attempt failed because ambitions far exceeded capabilities. The subsequent strategic reassessment emphasized a defensive stance behind a perimeter of fortified outposts built along the course of rivers and across the steppe that created an arbitrary and temporary state boundary for the empire. This defensive policy served a dual purpose. One was to corral the various ethnic groups which kept the frontier insecure because of their discords with the Russians and among themselves. The other was to create a secure environment for the advance of the Russian settler, develop an agricultural base to support a growing number of garrisons and Cossacks manning the forts, and encourage trade with the nomads alongside the perimeter. This brought about a subtle change in the execution of Russia's frontier policy. Its center of gravity moved from Kazan to Orenburg, from Tobolsk to Omsk, and the College of War with its military delegates in the field became the major architects of imperial policy. The great proconsuls of the first half of the eighteenth century - Gagarin, Volynskii, Kirilov, and Nepliuev were all civilians; by the end of the century, Potemkin, Igelstrom, Springer, and Strandmann were all lieutenant generals.

The increasingly dominant role played by the military was strengthened by the growing importance of the Caucasian sector, where the center of gravity moved from Astrakhan to Tiflis at the beginning of the nineteenth century, and also by the fact that the government hesitated throughout the period under consideration here between two contradictory policies: encouraging peasant migration from the Russian core to Siberia and the northern Caucasus versus the reluctance to let peasants migrate before the core population had reached a sufficient density to support the well-being of the ruling class and secure the operation of civil government. Reluctance prevailed most of the time, and Siberia became known perhaps unjustly so - as the land of runaways and convicts, of corruption and violence, the southeast as the land whose heroes remained Razin and Pugachev. No civilian government had the means to create there a « well-ordered police state ». ${ }^{81}$ Although Siberia had a civilian government, the proximity of the turbulent Kazakh steppe, Central Asia, and China gave military commanders a disproportionate influence. Transcaucasia was a war zone, and there was no alternative to military 
rule. But military rule, contemptuous of civilian authority and unchecked by the proximity of central agencies and some rudiments of civil society among the landed nobility, earned a bad reputation. When the Decembrist Andrei Rosen was transferred from Siberia to the Caucasus in 1838, he was told by a baker in Samara that he was indeed going from one hell to another (aus der Hölle in die Hölle). ${ }^{82}$ The Volga remained the border between hell and civilization. West of it, the colonization of the former lands of the Kazan and Astrakhan khanates had gone a long way to transform the provinces created in the 1770s into core area provinces with much higher densities of population than east of the river. Beyond it began «Asia » in the terminology of the time, where the first camels were visible across the river from Tsaritsyn on the edge of a featureless open steppe. In the south another world began beyond the Terek in the mountains of the Caucasus. There, beyond the Russian core, three lieutenant generals stood guard on the empire's periphery, waiting for an opportune moment to resume the advance that had begun under Peter the Great. When it did resume, in the 1850s, it was another lieutenant general, Nikolai Murav'ev, who would open the way from Irkutsk to Vladivostok and complete Russia's imperial infrastructure by anchoring it on the shores of the Pacific. 83

This broad survey of Russian administrative policy, distinct from military and foreign policy considerations which I have discussed elsewhere, raises a larger question requiring separate treatment. I have only briefly alluded to it here. Had the Russians been truly building an empire in the eastern theater since the conquest of Kazan in the middle of the sixteenth century, or had they been expanding the original Muscovite core and built an administrative, social, and military infrastructure to support the creation of an empire in the nineteenth century? It is remarkable that until the end of the seventeenth century the periphery of Russian settlement barely reached the boundary of the forest zone, and that the Russian realm beyond the Volga was hardly any different from that of the forest zone of the original Muscovite core. The eighteenth century witnessed the advance of the settler and the military outposts into the steppe, very much as the Muscovite core had expanded southwards into the wooded steppe toward the open steppe of the southern Ukraine. In the process, the Russians could reasonably expect to bring about the eventual conversion and integration into the Russian political and social order of Tatars, Bashkirs, Chuvash, Udmurts, and Mordvas in much the same way as they had assimilated the Urgo-Finnish tribes north of the Volga. It can therefore be claimed that the Russians were building not an empire but a unitary state in the

82. Andrei Rozen, Zapiski Dekabrista (Irkutsk: Vostochno-sibirskoe knizhnoe izdatel'stvo, 1984), 323. See also Nikolai S. Mordvinov, "Zaselenie Sibiri," in: Arkhiv grafov Mordvinovykh, Vol. 1-10 (SPb., 1901-1904), here vol. 8, 414-415. Others saw Siberia as both a "frightening heart of darkness and a fabulous land of plenty": see Galya Diment and Yuri Slezkine, eds., Between Heaven and Hell: The Myth of Siberia in Russian Culture (New York: St Martin's Press, 1993), 2.

83. Ivan Barsukov, Graf Nikolai Nikolaevich Murav'ev-Amurskii, vol. 1-2 (M., 1891), here vol. 1, 169-176. To continue the story told here see Anatolii V. Remnev, Samoderzhavie $i$ Sibir': Administrativnaia politika vtoroi poloviny XIX - nachala XX vekov (Omsk, 1997). 
form of an expanding core. The natural limits of that core must be the periphery of the agricultural zone into which the Russian peasant would settle but beyond which he would not go because that world was alien to him.

Those limits had nearly been reached by the end of the eighteenth century, in the Kazakh steppe, in the northern Caucasus, and even in eastern Siberia, where pockets of chernozem had attracted Russian settlers. That is why the administrative-territorial reform of the 1780 s must be seen as marking a recognition by the ruling elite that the time had come to impose a uniform set of local agencies across the entire eastern theater, those in Krasnioarsk identical, at least in principle, with those in Kaluga, Orel or Voronezh. But at the very same time that the reform was taking effect, the Treaty of Georgievsk announced Russian ambitions in Transcaucasia. Its annexation in the first two decades of the nineteenth century following wars with the Ottoman empire and Persia, the partitions of Poland, the annexation of the Polish core and the Russo-Swedish frontier in Finland, created an entirely different situation. It became impossible to speak convincingly of a continually expanding core, and the discourse had perforce to focus on the creation of an empire, on a duality between core and borderlands, into which the Russian peasant would never move (any more than into Central Asia fifty years later). But the old vision of an expanding core remained (« Russia, one and indivisible »), although increasingly divorced from reality. ${ }^{84}$ The creation of regional institutions with governors general and separate corps commanders reflected the emergence of an imperial policy — in Siberia, it was justified more by the great distances and the unsettled conditions in the steppe. Beginning in the 1820 s, the infrastructure of empire would rest on a tightly integrated core that was no longer expanding, but was becoming increasingly dependent on the resources of the imperial territories to support its great power pretensions.

\section{Davis Center for Russian Studies}

Harvard University

jledonne@fas.harvard.edu

84. Irina Dameshek calls this a contradictory policy, but does not develop the point by emphasizing the fact that the expanding core had reached its natural limits and could not continue to expand without ceasing to be a core and becoming an empire: I. Dameshek, Sibir' $v$ sisteme imperskogo regionalizma (komparativnoe issledovanie okrainnoi politiki Rossii $v$ pervoi polovine XIX V.) (Irkutsk, 2002), 46. 